\title{
Upstream and downstream migration speed of Prochilodus costatus (Characiformes: Prochilodontidae) in upper São Francisco basin, Brazil
}

\author{
João de Magalhães Lopes ${ }^{1}$, Carlos Bernardo Mascarenhas Alves², \\ Alexandre Peressin ${ }^{1,3}$ and Paulo Santos Pompeu ${ }^{1}$
}

Details of migration dynamics of Neotropical fishes are poorly understood. This study aimed to examine upstream (spawning) and downstream (post-spawning) migration speeds, of curimatá-pioa (Prochilodus costatus) in the São Francisco River basin, southeast Brazil. Most upstream movements were recorded in October and November, in two well-defined migration windows, and downstream movements were frequent from December to March. Fish migrated upstream at an average migration speed of $34.4 \mathrm{~km}_{\text {day }}{ }^{-1}$ and no significant differences were detected in their speed between sexes and migration window they selected to migrate. No relationship was detected between upstream migration speed and biometric measures of tagged individuals. Upstream migrations speeds were significantly higher for fish that swam longer prior to reach telemetry stations in the same season, indicating that swimming performance may take some time to achieve its peak in upstream migration. Fish migrated downstream at an average migration speed of $97.7 \mathrm{~km} \mathrm{day}^{-1}$, what is close to passive swimming in São Francisco River, and no significant differences in speed were detected between sexes or capture sites. The migration speeds measured here are the highest ever recorded for the genus Prochilodus and are among the highest reported for Neotropical migratory fish.

Keywords: Downstream migration, Migratory characteristics, Migration window, São Francisco River, Upstream migration.

Detalhes acerca da dinâmica migratória de peixes neotropicais são pouco conhecidos. O objetivo deste estudo foi analisar as velocidades em migração ascendente (reprodutiva) e descendente (pós-reprodutiva) da curimatá-pioa (Prochilodus costatus) no rio São Francisco, Brasil. A migração ascendente concentrou-se nos meses de outubro e novembro, em duas janelas migratórias, e a descendente de dezembro a março. Os peixes alcançaram velocidade migratória média de $34,4 \mathrm{~km} \mathrm{dia}^{-1}$ em migração ascendente não sendo observadas diferenças nas velocidades em relação ao sexo e janela migratória em que o peixe migrou. Não foi observada relação entre velocidade migratória e características biométricas dos peixes. Diferenças nas velocidades migratórias ascendentes foram observadas para peixes que nadaram maiores distâncias antes de passar pelas estações de telemetria, indicando que o pico de desempenho natatório é alcançado algum tempo depois de iniciado o movimento ascendente. Em migração descendente a média de velocidade migratória foi de $97,7 \mathrm{~km} \mathrm{dia}^{-1}$, próxima à natação passiva, e não foram observadas diferenças entre as velocidades em relação a sexo e ponto de marcação dos peixes. As velocidades migratórias medidas neste estudo são as maiores já registradas para o gênero Prochilodus e estão entre as maiores registradas para peixes migradores neotropicais.

Palavras-Chave: Características migratórias, Janela migratória, Migração ascendente, Migração descendente, Rio São Francisco.

\section{Introduction}

The Neotropical fish fauna is the most diverse on earth with over 5000 freshwater species described to date (Reis et al., 2016), some of which exhibit migratory behavior to some degree. Neotropical freshwater fish species that undertake long-distance migrations between spawning and feeding areas are mostly potamodromous and iteroparous
(Godinho et al., 2010), but there are many knowledge gaps with respect to specific aspects of their migration dynamics (Schulz, Leal, 2012). For example, there is a dearth of knowledge on the upstream and downstream migration speeds of the vast majority of tropical fish species (Lucas et al., 2001) and few studies have measured the speeds attained by Neotropical species during spawning and post-spawning migrations.

${ }^{1}$ Programa de Pós Graduação em Ecologia Aplicada, Universidade Federal de Lavras, Departamento de Biologia, Universitário, 37200-000 Lavras, MG, Brazil. (JML) jaolopes@hotmail.com, Dhttps://orcid.org/0000-0001-9558-0025 (corresponding author); (PSP) pompeups@gmail.com, Dhttps://orcid.org/0000-0002-7938-1517

${ }^{2}$ Bio-Ambiental Consultoria, Rua Rio de Janeiro, 1758/902, Lourdes, 30160-042 Belo Horizonte, MG, Brazil. cbmalves@gmail. com, Ohttps://orcid.org/0000-0002-1731-6541

${ }^{3}$ Cemig Geração e Transmissão S.A., Av. Barbacena, 1200, Santo Agostinho, 30190-131 Belo Horizonte, MG, Brazil. alexandre. peressin@gmail.com, Dhttps://orcid.org/0000-0003-0026-1713 
Even though data on swimming capacity derived from laboratory experiments is available for some species (Santos et al., 2009, 2012; Castro et al., 2010; Duarte et al., 2012; Sampaio et al., 2012; Duarte, Santos, 2014), little research has examined the swimming performance of Neotropical migratory species in natural river systems and most data are derived from mark-recapture studies that may considerably underestimate actual speeds (Godoy, 1975; Delfino, Baigun, 1985). Few studies have measured the migration speeds of Neotropical species during spawning or post-spawning migrations using field-collected biotelemetry data (Godinho et al., 2007; Andrade Neto, 2008; Fries, 2013; Pérez, 2014).

Knowledge of migration speeds of Neotropical freshwater fishes is essential for a better understanding of life history and migration characteristics including, among others, migration interval, energy costs of migration, and dates of arrival on spawning and feeding areas (Lucas et al., 2001). This information can be useful in the analysis of temporal changes in migration dynamics of migratory fish caused by hydrological disruption, for example damming and dredging by humans (Hanson et al., 2008). Human impacts that affect the swimming performance of migratory fish can increase travel times and reduce reproductive success through increased en route mortality and delayed arrival at spawning sites (Venditti et al., 2000).

Because knowledge of migration behavior in fishes is important for understanding their life cycles, this study aimed to measure the migration speeds of Prochilodus costatus Valenciennes, 1850 individuals during (upstream) spawning and (downstream) post-spawning migrations in the upper São Francisco River, Brazil.

\section{Material and Methods}

The São Francisco River is one of the largest rivers in Brazil, rising in the Canastra Mountains in southern Minas Gerais and flowing for $2,863 \mathrm{~km}$ before emptying into the Atlantic Ocean in Northeast Brazil (Fig. 1). Over 200 fish species have been described in its watershed, of which approximately $8 \%$ - usually those of greater commercial value and with higher yields - are considered migratory (Sato, Godinho, 2003). The study was conducted in the upper part of the basin along the lotic stretch upstream from the Três Marias reservoir, $400 \mathrm{~km}$ of free flow river, at the confluence of the São Francisco River and Pará River, one of its important tributaries. The climate of the region is characterized by a hot, wet season from October to April and a cool, dry season from May to September. The air temperature and water temperature follow a similar pattern, with higher temperatures recorded in the wet months and lower temperatures in the dry season.

The curimatá-pioa, $P$. costatus, is a migratory fish species endemic to the São Francisco River and one of the most important species for commercial fisheries across the entire basin (Sato, Godinho, 2003). The genus Prochilodus is composed of benthopelagic, detritivorous species that play a critical role in cycling organic material within the basins where they occur (Flecker, 1996; Stassen et al., 2010). Prochilodus is distributed across South America (Castro, Vari, 2004), and are considered long-distance migrants (Godoy, 1962; Bonetto et al., 1981; Sato, Godinho, 2003; Agostinho et al., 2004; Agostinho et al., 2007; Bailly et al., 2008). Fish of the genus Prochilodus are single batch spawners that produce semi-buoyant eggs with large perivitelline space that drift downstream over long distances (Godoy, 1975; Sato et al., 2003). Prochilodus costatus initiate spawning migration from September to December in the study area, triggered by rain and water level increase (Lopes et al., 2018a).

Two hundred and fifteen individuals of $P$. costatus were tagged with radiotelemetry transmitters (MCFT2-3EM, Lotek Wireless Inc.; $10 \mathrm{~g}$ in air; 5 to 6,5 seconds burst rate, 528-860 days of estimated life) from early September to mid-October for three consecutive years (2014 to 2016). Fish were captured and radio-tagged at two capture points, the first located in the São Francisco River (CSF) 10 rkm (river $\mathrm{km}$ ) upstream from the confluence with the Pará River and the second in the Pará River (CPA) 15 rkm upstream from the confluence with the São Francisco River (Fig. 1). The capture points were chosen to evaluate migratory characteristics of fish that reside in each river. In 2014, 43 were tagged in São Francisco River and 54 in Pará River. In 2015, 40 individuals were tagged in São Francisco and Pará rivers and in 2016, 38 fish were tagged only in Pará River. In the third year, fish were tagged only in Pará River (CPA) due to the number of available transmitters. Fish were captured with a cast net by boat and transported in aerated containers to the river bank where the tagging platform was installed. All fish were tagged within $24 \mathrm{~h}$ of capture, with most being tagged within a few hours. Tag burden did not exceed $2 \%$ of the weight of the fish (i.e., a minimum body weight of 500 g) as recommended in the literature (Nielsen, 1992; Winter, 1996). Voucher specimens were deposited at Lavras Federal University Ictiological Collection (CI-UFLA09989991000).

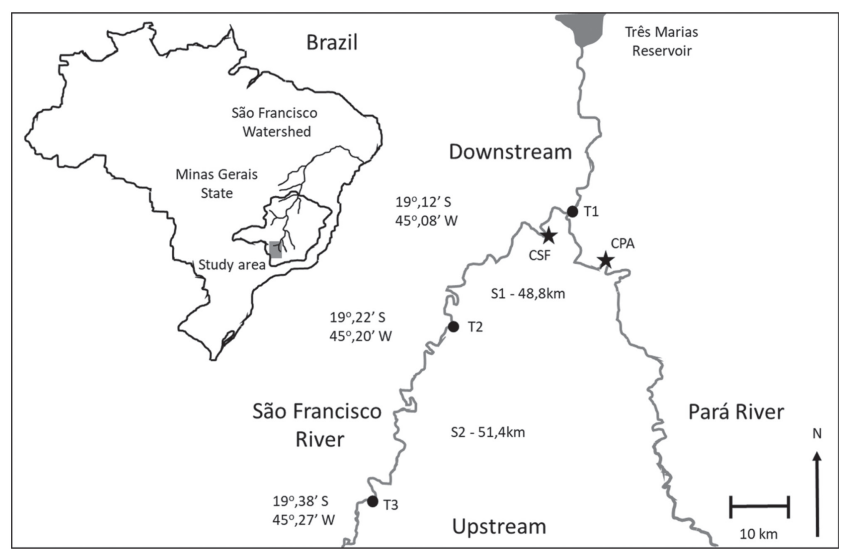

Fig. 1. Map of the São Francisco River watershed, Minas Gerais, Brazil detailing the study area in the upper part of the basin. CSF and CPA: capture/release points at São Francisco and Pará rivers; T1-T3: telemetry stations; $\mathrm{S} 1$ and $\mathrm{S} 2$ : river stretches. The length of river stretch is shown in river $\mathrm{km}$. 
The tagging protocol used was the one outlined by Lopes et al. (2016). Individuals selected for tagging were transferred to an aerated tank with eugenol $(0.05 \mathrm{mg} / \mathrm{L})$. Fish remained in the tank until they achieved stage IV anesthesia, which is characterized by loss of spontaneous movement (Summerfelt, Smith, 1990). After initial anesthesia, biometric data were collected and fish were transferred to the tagging platform. The allometric condition factor $\left(\mathrm{K}=\mathrm{W} / \mathrm{BL}^{\mathrm{b}}\right)$ of each individual fish was calculated using body (standard) length (BL) and weight (W) data. While on the tagging platform, fish were irrigated by a continuous flow of anesthetic (eugenol, $0.035 \mathrm{mg} / \mathrm{L}$ ) water pumped across the gills and a coded radio transmitter was implanted into the abdominal cavity through a small incision made in the ventral side posterior to the pelvic fins and lateral to the linea alba. The incision was closed with square knots using monofilament nylon sutures (0.200-0.249 $\mathrm{mm}$ in diameter; 4-5 per fish).

Sex was assigned for mature individuals during surgery based upon macroscopic characteristics (males: turgid and whitish testes; females: ovaries full of oocytes). If the gonad could not be visualized, the sex of the fish was classified as indeterminate. After the tagging procedure, fish were placed in a net pen in the river until fully recovered from surgery (sensu Lopes et al., 2016) and then released at the location of capture.

Three fixed telemetry stations were deployed $50 \mathrm{rkm}$ apart along the São Francisco River to track movements of radio-tagged individuals (Fig. 1). Each fixed station consisted of a data-logging radio receiver (SRX-DL, Lotek Inc.) connected to two five-element Yagi antennas, one directed upstream and one downstream. The moment of upstream and downstream fish passage was considered as the time with the highest signal strength captured by the two antennas in sequence and were recorded from September 2014 to June 2017. Detection tests were performed prior to fish tagging and detection range were estimated approximately at $300 \mathrm{~m}$ upstream and downstream from the receivers. Information on data handling procedures can be found in Lopes et al. (2018a, 2018b).

In this article, we used the definition of migration speed of Hanson et al. (2008). Migration speed ( $\mathrm{km} \mathrm{day}^{-1}$ or km $\mathrm{h}^{-1}$ ) is a measure of upstream and downstream fish migration movements and was calculated by dividing the distance between two successive fixed stations by the time interval between detection of an individual fish at those stations. The river stretches between fixed stations T1-T2 and T2T3 are hereafter referred to as stretch 1 (S1) and stretch 2 (S2), respectively (Fig. 1). Only records of fish passing by S2 were used to calculate the average migration speed for the species, because all tagged individuals (both fish tagged in São Francisco and Pará rivers) were recorded migrating upstream and downstream through this stretch.

To calculate the swimming speed of curimatá-pioa, the average current speed in the São Francisco River was estimated by the relationship between discharge and velocity using daily discharge data recorded by the Minas Gerais energy company (CEMIG) approximately $30 \mathrm{rkm}$ upstream from the confluence with the Para River. The individual swimming speed expressed in standard length per second $\left(\mathrm{BL} \mathrm{s}^{-1}\right)$ was then calculated for $\mathrm{S} 2$ according to the formula:

Swimming speed $=((\operatorname{Lr} / \mathrm{T})+\mathrm{C}) / \mathrm{BL}$, where:

$\mathrm{Lr}=$ length of river stretch between fixed stations (m);

$\mathrm{T}=$ time interval between fixed stations ( $\mathrm{s}$ );

$\mathrm{C}=$ estimated average current speed $\left(\mathrm{m} \mathrm{s}^{-1}\right)$;

$\mathrm{BL}=$ standard length of fish (m).

The upstream migration speed of males and females along S2 was compared for fish captured in the São Francisco and Pará rivers using two-way analysis of variance (ANOVA). In addition, migration speeds in S2 of fish captured in the São Francisco and Pará rivers and fish migrating at different flux intervals were compared using two-way ANOVA. Two curimatá-pioa peak migration windows, with high migration flux, were identified for the area over a three-year period. The first migration flux period is in October and the second in November, each lasting on average 11-14 days separated by a 12 to 20-day period with no migration movements occurring between them (Lopes et al., 2018b). A paired t test was used to compare the upstream migration speeds of the same individuals in the two São Francisco River stretches (S1 and S2). Downstream migration speeds were compared between sexes and capture sites using the Mann-Whitney test and between stretches using the Wilcoxon test because the data were not normally distributed. To determine the repeatability of upstream migration speeds by individuals (i.e., if individuals retain their rank with respect to migration speed from S1 to S2), the correlation between the rank order of individual migration speeds between the two river stretches was assessed using the Spearman's rank correlation coefficient test. The relationship between biometric data (standard length, body weight, and allometric condition factor) and upstream migration speed along S2 was analyzed using multiple regression analysis. All values, unless indicated, represent means \pm SD. Results were considered significant at $\mathrm{p}<0.05$.

\section{Results}

Sixty-four fish (29,8\% of the total 215$)$ provided upstream migration data and 45 of them provided downstream migration data. Three fish $(1,4 \%)$ migrated by Pará River and eight $(3,7 \%)$ migrated downstream to Três Marias reservoir what made it impossible to measure their migration speed. Seventeen $(7,9 \%)$ individuals were recaptured during the study period and had their tags returned. Twenty-one $(9,7 \%)$ were recorded migrating upstream by $\mathrm{T} 1$ but did not reach T2 indicating that their spawning sites were located between those receivers or that they were fished at this river stretch and not reported. Thirty-seven fish $(17,2 \%)$ were not detected or were only detected once after tagging, suggesting that they 
may have been fished or had a malfunctioning transmitter. Sixty-five $(30,2 \%)$ remained very close to release sites, suggesting that they may not have migrated in that season or have died as a result of post-tagging complications.

Upstream movements were recorded from September to December (four months). Downstream movements were mostly recorded from September to May (nine months), and the mean period of residence at spawning sites were 89 days (for more information on the life cycle of $P$. costatus see Lopes et al., 2018b). River water velocity averages were $0.62,0.78$ and $0.66 \mathrm{~m} / \mathrm{s}$ for $2014 / 15,2015 / 16$ and $2016 / 17$ migration seasons respectively.

Prochilodus costatus Curimatá-pioa individuals migrated upstream at an average migration speed of $34.4 \pm$ $10.6 \mathrm{~km}$ day $^{-1}$ (range: $2.8-59.3 \mathrm{~km} \mathrm{day}^{-1}$ ) and downstream at an average migration speed of $97.7 \pm 42.9 \mathrm{~km}^{-1 a y^{-1}}$ (range: 4.0-155.6 km day ${ }^{-1}$ ) (Fig. 2).

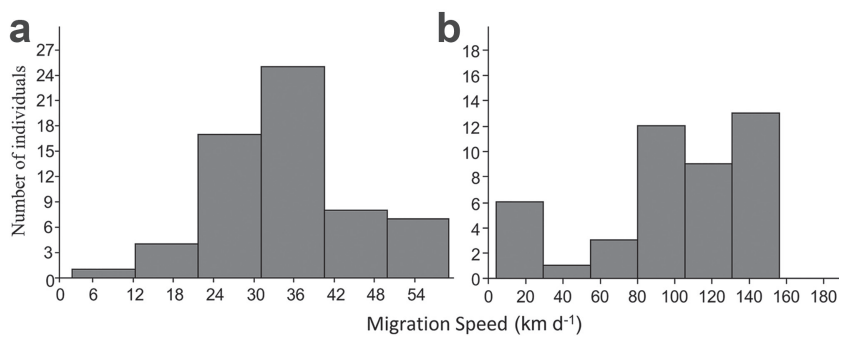

Fig. 2. Distribution of migration speed $\left(\mathrm{km} \mathrm{d}^{-1}\right)$ of Prochilodus costatus in a. up and b. downstream migration of tagged fish.

No significant difference in upstream migration speed was detected between males ( 15 individuals; $\mathrm{BL}=33.6 \pm 2.62$ $\mathrm{cm}, \mathrm{W}=912.5 \pm 216.8 \mathrm{~g}$ ) and females (23 individuals; BL $=38.3 \pm 2.87 \mathrm{~cm}, \mathrm{~W}=1362.9 \pm 357.5 \mathrm{~g}$; two-way ANOVA, $\mathrm{p}=0.19$ ) captured in the São Francisco and Pará rivers (Fig. 3a). The average migration speed of fish captured in the Pará River that were detected passing the three fixed stations was significantly higher in S2 than S1 (paired Student's t test, $p$ $<0.001$; Fig. 3b). The average migration speed in S2 was significantly higher for fish captured in the Pará River than the São Francisco River (two-way ANOVA, $p=0.02$; Fig. $3 c$ ), but there was no significant difference in migration speed between peak migration flux periods (October and November) (two-way ANOVA, $\mathrm{p}=0.13$; Fig. 4d) and no significant interaction was detected between capture site and timing of migration (two-way ANOVA, $\mathrm{p}=0.09$ ).

No significant differences in downstream migration speeds were detected between males and females (MannWhitney test, $p=0.14$ ), river stretches (Wilcoxon test, $p=$ 0.06 ), or capture sites (Mann-Whitney test, $p=0.20$; Fig. 4).

Fish that swam faster in the first river stretch (S1) were also faster in S2 (Spearman's rank correlation, $\rho=0.466$, $p$ $<0.002$; Fig. 5). Multiple regression analysis revealed no significant relationship between standard length $(\mathrm{p}=0.06)$, body weight $(\mathrm{p}=0.09)$, or allometric condition factor $(\mathrm{p}=$ 0.15 ) with upstream migration speed.

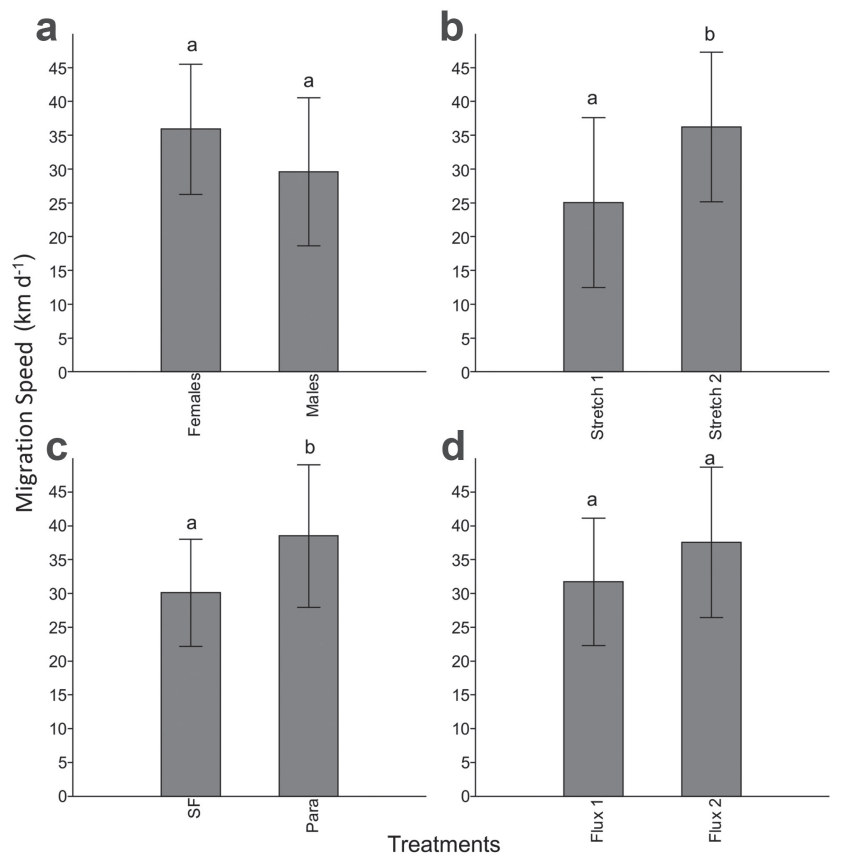

Fig. 3. Comparison of average up-river migration speed of Prochilodus costatus in a. males and females, b. river stretches for fish captured in the Pará River, c. fish captured in the Pará River and São Francisco River in S2, and d. migration intervals in S2. Bars represent the standard deviation. Different letters denote statistically significant differences in migration speed. S1 and S2: river stretches.

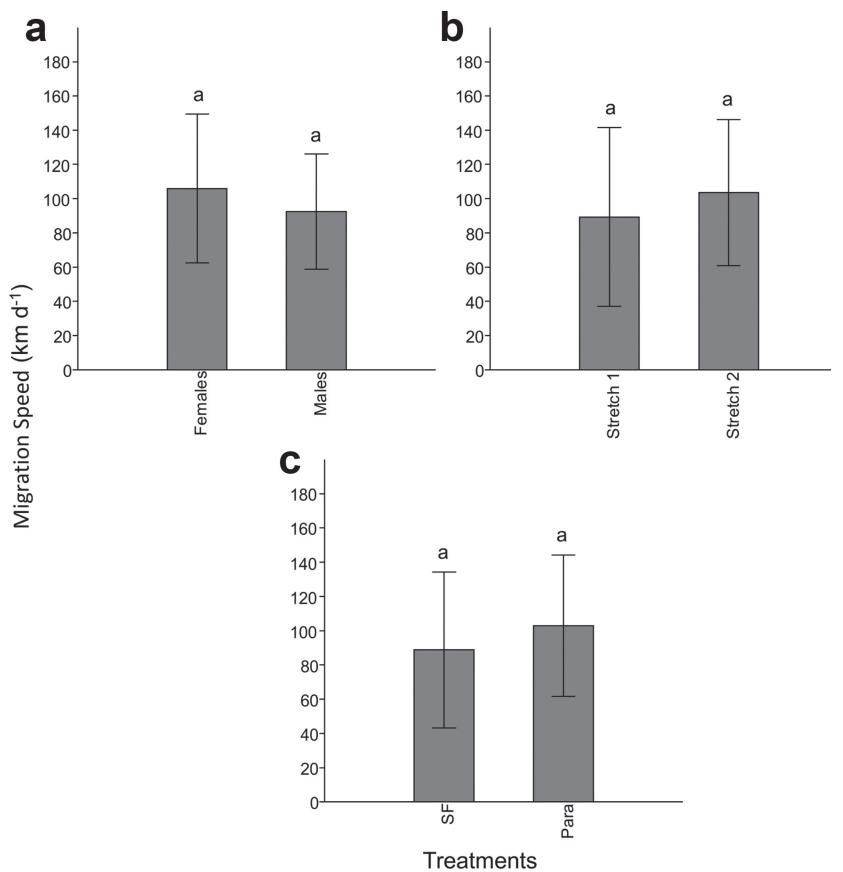

Fig. 4. Comparison of average downstream migration speeds of Prochilodus costatus in the São Francisco River between a. males and females, $\mathbf{b}$. river stretches, and $\mathbf{c}$. fish captured in the Pará River and São Francisco River in S2. Bars represent the standard deviation. Different letters denote significant differences in migration speed. S1 and S2: river stretches. 


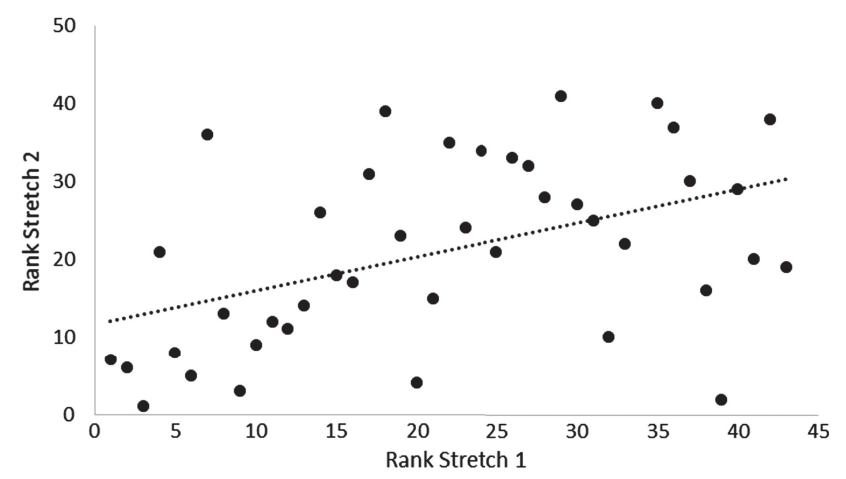

Fig. 5. Correlation between the rank order of individual migration speeds between stretch 1 (S1) and stretch 2 (S2). $\mathrm{r}^{2}$ value $=0.214$

Fish migrating upstream swam at an average swimming speed of $2.41 \pm 0.79 \mathrm{BL} \mathrm{s}^{-1}$, which is within the range of sustained speeds for the species, whereas the average downstream swimming speed $\left(0.09 \pm 1.33 \mathrm{BL} \mathrm{s}^{-1}\right)$ was close to water current speeds, indicating that most individuals returning drift downstream (Fig. 6).

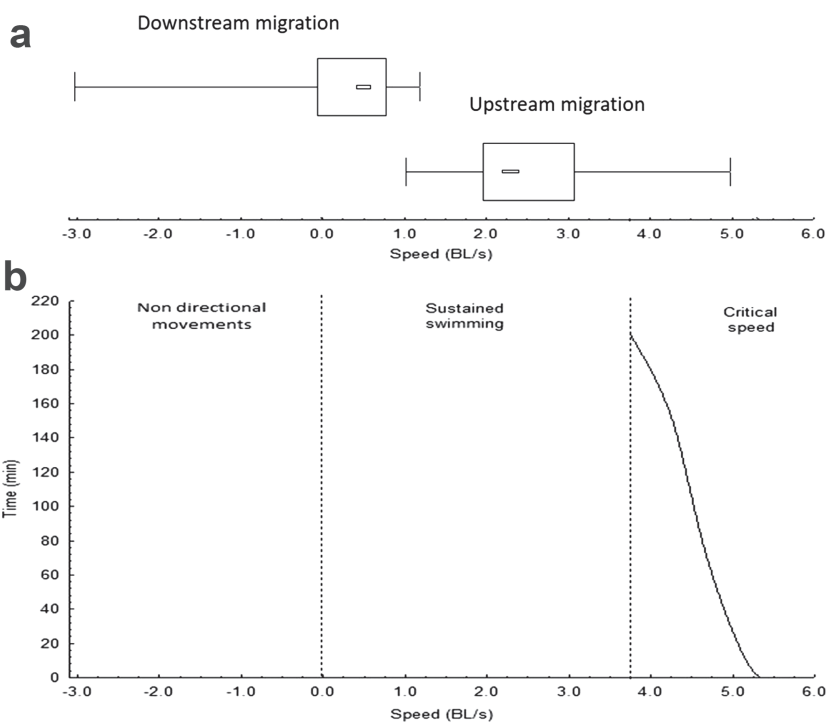

Fig. 6. Prochilodus costatus swimming speeds measured a. in this study in stretch 2 and $\mathbf{b}$. in the laboratory by Santos et al. (2012). Central points are medians, boxes represent percentiles 25 and 75 and whiskers represent amplitude. Dashed lines separate different kinds of fish movements. BL/s $=$ swimming velocity in standard length of fish per second.

\section{Discussion}

This study provides migration speed data of a large number of individuals migrating through an undammed free-flowing river section in the Neotropical region, using biotelemetry. The average and maximum migration speeds achieved by $P$. costatus, both in upstream and downstream movements, are the highest ever recorded for fish in the Prochilodus and are among the highest reported for Neotropical fish, suggesting that the swimming capacity of this group is higher than what had previously been estimated in field studies. Table 1 shows a summary of the results of studies that provide data on migration speeds for Neotropical fish. However, none of these studies were designed specifically to determine migration speeds. Thus, the migration speeds reported by these studies were often based on a small number of individuals or even a single individual. Additionally, some of these migration speeds were recorded in mark-recapture studies (Tab. 1) that may have considerably underestimated actual migration speeds, or in studies conducted in dammed river sections or reservoirs formed by river impoundment, which may affect the swimming behavior of tagged individuals.

The relative low percentage of fish that provided migration speeds data are explained by different factors. Few studies have measured mortality rates of Neotropical fish after tagging. Lopes et al. (2016) found low mortality rates in surgical controlled conditions at a hatchery, but $20 \%$ of tagged fish presented some sort of clinical complication, what could lead to long term mortality. In the field such numbers should be higher than in hatchery conditions. Additionally, not all fish tagged in a given year migrate to spawn. Some of the individuals seen to remain at the feeding sites, depending on the quantity and quality of environmental triggers available in that spawning season (Lopes et al., 2018a). Rates of not reported recaptures are also difficult to estimate. Fishing is a very common activity in the region (personal observation), even during the reproduction prohibition period that lasts from November to February. Some transmitter signals were obtained above cities nearby the study area during aerial tracking, indicating that fishing can be a significant source for lost individuals.

The main spawning sites of tagged curimatá-pioa in the study area were mapped through aerial surveys and egg and larva collection were $250-350 \mathrm{rkm}$ away from capture sites (Lopes et al., 2018b), indicating that these individuals still must travel 150-250 rkm to reach their spawning location after passing fixed station T3. Assuming average upstream migration speeds of $P$. costatus in the remainder of the spawning migration route remain close to those measured in stretch 2 , individuals should arrive at spawning sites within a relatively short period of 7-20 days. In fact, data gathered by an aerial survey in October of 2015 showed three fish at their reproductive site, located $240 \mathrm{~km}$ upstream from T3, nine to twenty days after passing this station (Lopes, 2017). It shows that they reached those points at the expected period predicted by the specie migration speeds. Lucas et al. (2001) estimated a travel time of 74 days for Prochilodus magdalenae Steindachner, 1879 traveling an upstream distance of $250 \mathrm{rkm}$ in their migration, whereas Toledo et al. (1986) reported travel times of 2.5-3.0 months for the $650 \mathrm{rkm}$ spawning migration of Prochilodus lineatus (Valenciennes, 1837) between the Grande and Mogi-Guaçu rivers. The much shorter mean travel time of seven to twenty days estimated in this study for $P$. costatus to cover an upstream distance of 250-350 rkm indicates that some Neotropical species may have shorter travel times than previously estimated. 


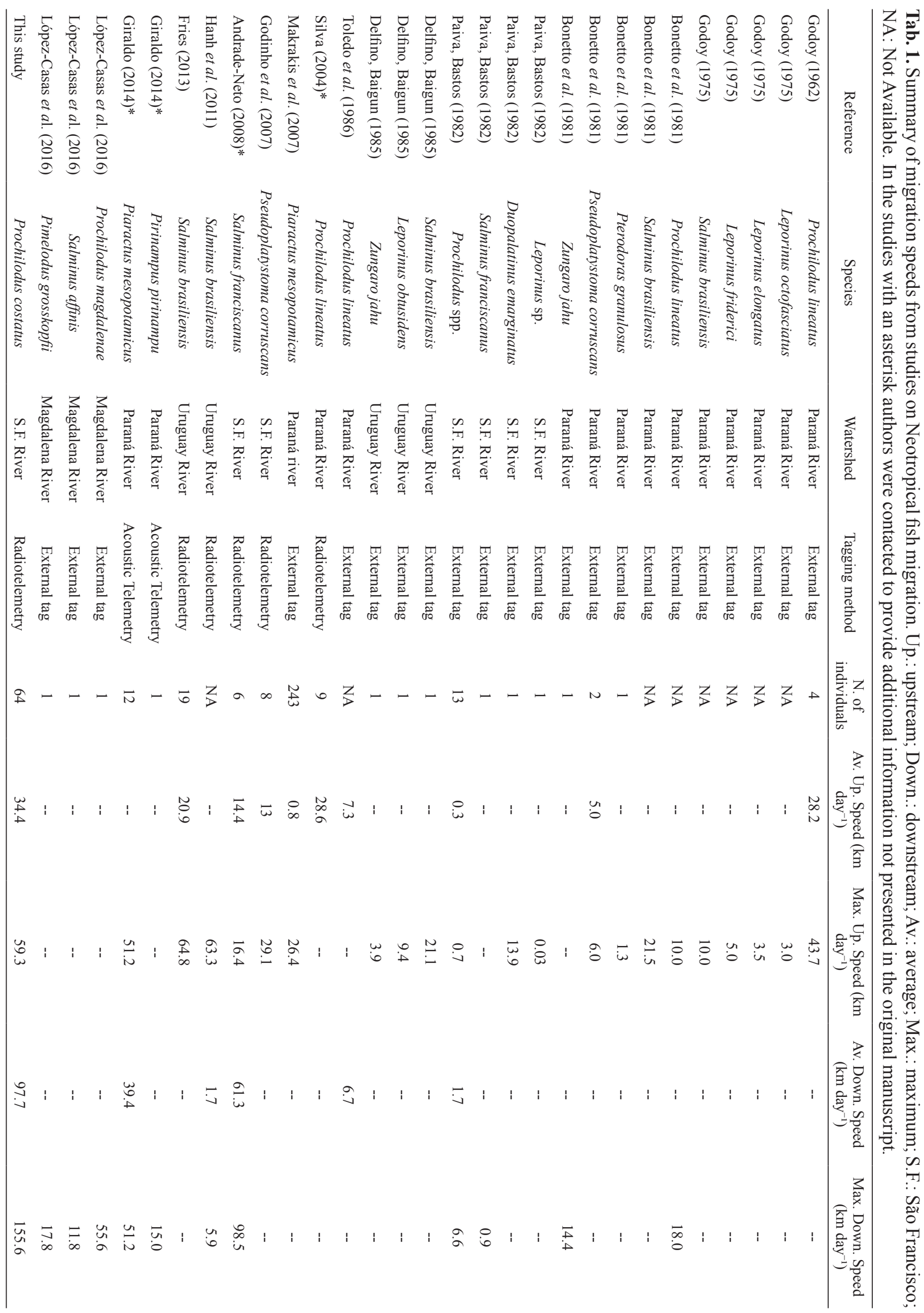


Upstream migration speeds of fish captured in the Pará River were higher in S2 than S1. One possibility for this difference is that the São Francisco River channel may be more difficult to traverse along S1 than S2. However, aerial surveys revealed no hydrographic features such as rapids or channel constrictions in S1 that could explain this difference. In addition, fish captured in the Pará River swam faster upstream through S2 than fish captured in the São Francisco River. Because fish captured in the Pará River traveled a longer distance to reach S2 (15 rkm downstream in the Pará River and $10 \mathrm{rkm}$ upstream in the São Francisco River) than fish captured in the São Francisco River, these data suggest that curimatá-pioa can increase their migration speed along the migration route. It can happen since muscles and physiological mechanisms recruited for long-distance upstream migrations may require some time to achieve optimum performance. It may take some time for this process to reach its peak after the initiation of movement. Thus, average upstream migration speeds of $P$. costatus appear to increase during the first kilometers traveled and if this gradual increase in speed through the São Francisco River occurs beyond S2 - actual speeds may be even higher than those recorded in this study. This should be better investigated in future studies.

No significant differences in upstream migration speed were detected between males and females. In addition, no relationship was detected between migration speed and biometric data of tagged individuals. Thus, larger and heavier individuals did not swim faster or slower than smaller, lighter ones. López-Casas et al. (2016) found similar results for migratory fish of Magdalena River, in Colombia. Timing of upstream migration was not correlated with migration speeds. Migration speeds of fish migrating in the October flux peak were similar to those of individuals moving upstream in the November peak. Fish that initiate migration later are expected to swim faster to reach the spawning sites (Lucas et al., 2001), but this was not observed in P. costatus. This finding indicates that travel time to spawning sites is not limiting spawning of $P$. costatus in the study region, even for individuals that commence migration later, and may be explained by the relatively short distances between feeding areas and spawning sites (250-350 rkm).

Fish that traveled faster in the first river stretch (S1) also tended to be faster in the second stretch (S2). Individual differences in migration speed reflect individual variation in swimming performance (Hinch, Rand, 1998; Hinch et al., 2002; Keefer et al., 2004). Genetic and ecological aspects have been implicated in these differences, which are heritable traits (Martínez et al. 2001; Claireaux et al. 2007). The distance to spawning sites, for example, has been noted to affect swimming performance. In Pacific salmon, it has been documented that individuals that migrate long distances are characterized by short bodies and they typically have higher reserve energy than do individuals that migrate short distances (Crossin et al., 2004; Hanson et al., 2008). These phenotypic differences enable individuals to minimize energy depletion during transit to spawning sites (Hanson et al., 2008). Even though P. costatus exhibited individual variation in migration speeds, more research into the physiological and ecological mechanisms responsible for these differences is required.

Downstream migration speeds were higher than upstream speeds but very similar to current speeds measured in the São Francisco River, indicating that return migration to feeding areas occurs mainly by passive drift for most individuals. This phenomenon has been previously observed among some Neotropical migratory species (Godoy, 1975; Bonetto et al., 1981; Lucas et al., 2001) and, because downstream migration speed is largely determined by current speed, it may explain the lack of significant differences in downstream migration speed of curimatá-pioa between sexes, capture sites, and river stretches. However, there is variation in downstream migration speeds among individuals, probably because river water velocity also presents variation between December and March due to rainfall and because some individuals could present an active behavior while migrating downstream. The high amplitude of migration velocities indicates that some individuals might be in active swimming, both in the direction of the current and on exploratory movements against it, during downstream migration. The fact that most curimatá-pioa migrating downstream exhibit passive drift reinforces the negative impact that large reservoirs with low flow velocity may exert on Neotropical migratory species (Pelicice et al., 2015). Large reservoirs not only act as a barrier to drifting eggs and larvae of migratory fish, but they also create a diffuse gradient of hydraulic conditions that discourages downstream migration of adults.

Optimum swimming speeds at prolonged mode estimated by respirometer data are usually lower than those recorded in volitional tests, when fish are voluntarily sprinted up in an open-channel flume against fixed flow velocities (Castro-Santos, 2005). Differences in the results of forced swimming experiments and volitional tests can be attributed to differences in energy costs for confined and unconfined swimming (Peake, 2004). However, the swimming speeds measured in the current study are similar to the maximum sustained swimming speeds attained by $P$. costatus in a respirometer (Santos et al., 2012), showing that those tests can present close results to field velocities performed by Neotropical fish.

These results help to shed light on the poorly understood phenomenon of Neotropical fish migration. Even though general information on the migration dynamics of Neotropical freshwater fishes has been made available in recent years (Harvey, Carolsfeld, 2003; Godinho, Pompeu, 2003; Pompeu, Godinho, 2006; Godinho, Kynard, 2006, 2009; Agostinho et al., 2007; Godinho et al., 2007, 2010; Bailly et al., 2008; Hanh et al., 2011; Makrakis et al., 2012; Lopes et al., 2018b), details of migratory characteristics such as upstream and downstream migration speeds are still scarce. By using a radiotelemetry array we were able to determine the swimming performance of $P$. costatus 
individuals in the study region and provide estimates of travel times for spawning and post-spawning migrations. Our results can serve as the basis for comparison with future studies on the migration speed of other Neotropical migratory species and its relationship with life history characteristics, including the distances traveled, migration departure time, and the habitat characteristics of the regions where they occur. Further research that provides robust and detailed information about the migratory characteristics of Neotropical fishes will contribute to the development of effective conservation strategies for this group of fishes, as in the case of fish passages design that take in account the swimming features of this group.

\section{Acknowledgments}

The authors thank Cemig/Aneel Research and Development program for financial support. Paulo Santos Pompeu was awarded a productivity in research grant by $\mathrm{CNPq}$ - Conselho Nacional de Desenvolvimento e Pesquisa (CNPq No. 303548/2017-7) and a Minas Gerais State Researcher Grant by Fundação de Amparo à Pesquisa do Estado de Minas Gerais (FAPEMIG PPM-00608/15). Capture and tagging licence was granted by Brazilian Environmental Ministry. We also thank Diego Castro from UFMG for graphical support.

\section{References}

Agostinho AA, Gomes LC, Veríssimo S, Okada EK. Flood regime, dam regulation and fish in the upper Paraná River: effects on assemblage attributes, reproduction and recruitment. Rev Fish Biol Fisher. 2004; 14(1):11-19.

Agostinho AA, Gomes LC, Pelicice FM. Ecologia e manejo dos recursos pesqueiros em reservatórios do Brasil. Maringá: EDUEM; 2007.

Andrade Neto FR. Migração e conservação do dourado (Salminus franciscanus, Lima \& Britski 2007) em um trecho do rio São Francisco. [MSc Dissertation]. Belo Horizonte, MG: Universidade Federal de Minas Gerais; 2008.

Bailly D, Agostinho AA, Suzuki HI. Influence of the flood regime on the reproduction of fish species with different reproductive strategies in the Cuiabá River, upper Pantanal, Brazil. River Res Appl. 2008; 24(9):1218-29.

Bonetto AA, Canon-Verón M, Roldán D. Nuevos aportes al conocimiento de las migraciones de peces en el rio Paraná. ECOSUR. 1981; 8(16):29-40.

Castro MA, Santos HA, Sampaio FAC, Pompeu PS. Swimming performance of the small-sized characin Bryconamericus stramineus (Characiformes: Characidae). Rev Bras Zool. 2010; 27(6):939-44.

Castro RMC, Vari RP. Detritivores of the South American fish family Prochilodontidae (Teleostei: Ostariophysi: Characiformes): a phylogenetic and revisionary study. Washington (DC): Smithsonian Institution Press; 2004. (Smithsonian Contributions to Zoology; No. 622).
Castro-Santos T. Optimal swim speeds for traversing velocity barriers: an analysis of volitional high-speed swimming behavior of migratory fishes. J Exp Biol. 2005; 208(3):421-32.

Claireaux G, Handelsman C, Standen E, Nelson JA. Thermal and temporal stability of swimming performance in the European sea bass. Physiol Biochem Zool. 2007; 80(2):186-96.

Crossin GT, Hinch SG, Farrell AP, Higgs DA, Lotto AG, Oakes JD, Healey MC. Energetics and morphology of sockeye salmon: effects of upriver migratory distance and elevation. J Fish Biol. 2004; 65(3):788-810.

Delfino R, Baigun CRM. Marcaciones de peces en el embalse de Salto Grande, rio Uruguay (Argentina-Uruguay). Rev Asoc Cienc Nat Litor. 1985; 16(1):85-93.

Duarte BAF, Ramos ICR, Santos HA. Reynolds shear-stress and velocity: positive biological response of neotropical fishes to hydraulic parameters in a vertical slot fishway. Neotrop Ichthyol. 2012; 10(4):813-19.

Duarte BAF, Santos HA. Tensão de Reynolds e velocidade média em uma escada para peixes do tipo ranhura vertical: comportamento preferencial da espécie Leporinus reinhardti. Rev Bras Recur Hídricos. 2014; 19(2):157-67.

Flecker AS. Ecosystem engineering by a dominant detritivore in a diverse tropical stream. Ecology. 1996; 77(6):1845-54.

Fries LCC. Movimentos e distribuição longitudinal de um peixe migrador (Salminus brasiliensis) em um reservatório de usina hidrelétrica. [MSc Dissertation]. Porto Alegre, RS: Universidade Federal do Rio Grande do Sul; 2013.

Godinho AL, Kynard B. Migration and spawning of radio-tagged zulega Prochilodus argenteus in a dammed brazilian river. Trans Am Fish Soc. 2006; 135(3):811-24.

Godinho AL, Kynard B. Migratory fishes of Brazil: life history and fish passage needs. River Res Appl. 2009; 25(6):702-12.

Godinho AL, Pompeu PS. A importância dos ribeirões para os peixes de piracema. In: Godinho HP, Godinho AL, editors. Águas, peixes e pescadores do São Francisco das Minas Gerais. Belo Horizonte: PUC Minas; 2003. p.361-372.

Godinho AL, Kynard B, Godinho H. Migration and spawning of female surubim (Pseudoplatystoma corruscans, Pimelodidae) in the São Francisco River, Brazil. Environ Biol Fishes. 2007; 80(4):421-33.

Godinho AL, Lamas IR, Godinho HP. Reproductive ecology of Brazilian freshwater fishes. Environ Biol Fishes. 2010; 87(2):143-62.

Godoy MP. Marcação, migração e transplantação de peixes marcados na bacia do rio Paraná superior. Arq Mus Nac. 1962; 52:105-13.

Godoy MP. Peixes do Brasil, sub-ordem Characoidei, bacia do Rio Mogi-Guaçu. Piracicaba: Editora Franciscana; 1975.

Hahn L, Agostinho AA, English KK, Carolsfeld J, Câmara LF, Cooke SJ. Use of radiotelemetry to track threatened dorados Salminus brasiliensis in the upper Uruguay River, Brazil. Endanger Species Res. 2011; 15(2):103-14.

Hanson KC, Cooke SJ, Hinch SG, Crossin GT, Patterson DA, English KK, Donaldson MR, Shrimpton JM, van der Kraak G, Farrell AP. Individual variation in migration speed of uprivermigrating sockeye salmon in the Fraser River in relation to their physiological and energetic status at marine approach. Physiol Biochem Zool. 2008; 81(3):255-68. 
Harvey B, Carolsfeld JB. Introduction: fishes of the floods. In: Carolsfeld J, Harvey B, Ross C, Baer A, editors. Migratory fishes of South America: biology, fisheries and conservation status. Victoria: World Fisheries Trus: The World Bank \& The International Development Research Centre; 2003. p.1-18.

Hinch SG, Rand PS. Swim speeds and energy use of uprivermigrating sockeye salmon (Oncorhynchus nerka): role of local environment and fish characteristics. Can J Fish Aquat Sci. 1998; 55(8):1821-31.

Hinch SG, Standen EM, Healey MC, Farrell AP. Swimming patterns and behaviour of upriver migrating adult pink (Oncorhynchus gorbuscha) and sockeye (O. nerka) salmon as assessed by EMG telemetry in the Fraser River, British Columbia. Hydrobiologia. 2002; 483(1-3):147-60.

Keefer ML, Peery CA, Jepson MA, Tolotti KR, Bjornn TC, Stuehrenberg LC. Stock-specific migration timing of adult spring-summer chinook salmon in the Columbia River basin. N Am J Fish Manag. 2004; 24(4):1145-62.

Lopes JM, Alves CBM, Silva FO, Bedore AG, Pompeu PS. Effect of anesthetic, tag size, and surgeon experience on postsurgical recovering after implantation of electronic tags in a neotropical fish: Prochilodus lineatus (Valenciennes, 1837) (Characiformes: Prochilodontidae). Neotrop Ichthyol. 2016; 14(3): e150189. Available from: http://dx.doi.org/10.1590/1982-022420150189

Lopes JM. Dinâmica migratória de uma espécie reofílica de peixe (Phochilodus costatus) no alto São Francisco, MG: diferenças entre populações locais e transpostas e implicações para a instalação de um sistema de transposição de peixes na UHE Três Marias. [PhD Thesis]. Lavras, MG: Universidade Federal de Lavras; 2017.

Lopes JM, Alves CBM, Peressin A, Pompeu PS. Influence of rainfall, hydrological fluctuations, and lunar phase on spawning migration timing of the Neotropical fish Prochilodus costatus. Hydrobiologia 2018a; 818(1):145-61.

Lopes JM, Pompeu PS, Alves CBM, Peressin A, Prado IG, Suzuki FM, Facchin S, Kalapothakis E. The critical importance of an undammed river segment to the reproductive cycle of a migratory Neotropical fish. Ecol Freshw Fish. 2018b; 28(2):302-06. Available from: https://doi.org/10.1111/ eff. 12454

López-Casas S, Jiménez-Segura LF, Agostinho AA, Pérez CM. Potamodromous migrations in the Magdalena River basin: bimodal reproductive patterns in neotropical rivers. J Fish Biol. 2016; 89(1):157-71.

Lucas MC, Baras E, Thom TJ, Duncan A, Slavík O, editors. Migrations of freshwater fishes. Oxford: Blackwell Science; 2001.

Makrakis MC, Miranda LE, Makrakis S, Xavier AMM, Fontes HM, Morlis WG. Migratory movements, Piaractus mesopotamicus, in the highly impounded Paraná. River. J Appl Ichthyol. 2007; 23(6):700-04.

Makrakis MC, Miranda LE, Makrakis S, Fontes Júnior HM, Morlis WG, Dias JHP, Garcia JO. Diversity in migratory patterns among Neotropical fishes in a highly regulated river basin. J Fish Biol. 2012; 81(2):866-81.
Martínez M, Guderley H, Nelson JA, Webber D, Dutil JD. Once a fast cod, always a fast cod: maintenance of performance hierarchies despite changing food availability in cod (Gadus morhua). Physiol Biochem Zool. 2001; 75(1):90-100.

Nielsen LA. Methods of marking fish and shellfish. Bethesda: American Fisheries Society; 1992.

Paiva MP, Bastos SA. Marcações de peixes nas regiões do alto e médio São Francisco (Brasil). Ciênc Cult. 1982; 34(10):1362-65.

Peake S. An evaluation of the use of critical swimming speed for determination of culvert water velocity criteria for smallmouth bass. Trans Am Fish. Soc. 2004; 133(6):147279.

Pelicice FM, Pompeu PS, Agostinho AA. Large reservoirs as ecological barriers to downnstream movements of Neotropical migratory fish. Fish Fish. 2015; 16(4):697-715.

Pérez AG. Movimentos e mortalidade crônica de peixes nos rios Grande e Paranaíba, MG. [PhD Thesis]. Belo Horizonte, MG: Universidade Federal de Minas Gerais; 2014.

Pompeu PS, Godinho HP. Effects of extended absence of flooding on the fish assemblages of three floodplain lagoons in the middle São Francisco River, Brazil. Neotrop Ichthyol. 2006; 4(4):427-33.

Reis RE, Albert JS, Di Dario F, Mincarone MM, Petry P, Rocha LA. Fish biodiversity and conservation in South America. J Fish Biol. 2016; 89(1):12-47.

Sampaio FAC, Pompeu PS, Santos HA, Ferreira RL. Swimming performance of epigeal and hypogeal species of Characidae, with an emphasis on the troglobiotic Stygchthys typhlops Brittan \& Bohlke, 1965. Int J Speleol. 2012; 41(1):9-16.

Santos HA, Pompeu PS, Martinez CB. Estabelecimento de parâmetros hidráulicos para escadas de peixes do tipo ranhura vertical baseados em características de espécies neotropicais. Rev Bras Recur Hídricos. 2009; 14(1):99-112.

Santos HA, Viana EMF, Pompeu PS, Martinez CB. Optimal swim speeds by respirometer: an analysis of three neotropical species. Neotrop Ichthyol. 2012; 10(4):805-11.

Sato Y, Godinho HP. Migratory fishes of the São Francisco River. In: Carolsfeld J, Harvey B, Ross C, Baer A, editors. Migratory fishes of South America: biology, fisheries and conservation status. Victoria, BC: World Fisheries Trust; The World Bank \& The International Development Research Centre; 2003. p.195-232.

Sato Y, Fenerich-Verani N, Nuñer APO, Godinho HP, Verani JR. Padrões reprodutivos de peixes da bacia do São Francisco. In: Godinho HP, Godinho AL, organizers. Águas, peixes e pescadores do São Francisco das Minas Gerais. Belo Horizonte: PUC Minas; 2003. p.229-274.

Schulz UH, Leal ME. Effects of stocking density on dispersal behavior of Brazilian freshwater dourado (Salminus brasiliensis) in a subtropical river headwater. Neotrop Ichthyol. 2012; 10(2):409-15.

Silva LGM. Migração de mandis-amarelos Pimelodus maculatus e curimbas Prochilodus lineatus no rio Grande, bacia do Alto Paraná. [MSc Dissertation]. Belo Horizonte, MG: Pontifícia Universidade Católica de Minas Gerais; 2004. 
Stassen MJM, van de Ven MWPM, van der Heide T, Hiza MAG, van der Velde G, Smolders AJP. Population dynamics of the migratory fish Prochilodus lineatus in a neotropical river: the relationships with river discharge, flood pulse, El Nino and fluvial megafan behaviour. Neotrop Ichthyol. 2010; 8(1):113-22.

Summerfelt RC, Smith LS. Anesthesia, surgery and related techniques. In: Schreck CB, Moyle PB, editors. Methods for fish biology. Bethesda, MD: American Fisheries Society; 1990. p.213-272.

Toledo SA, Godoy MP, Dos Santos EP. Curve of migration of curimbata, Prochilodus scrofa (Pisces, Prochilodontidae) in the upper basin of the Paraná River, Brazil. Rev Bras Biol. 1986; 46(2):447-52.
Venditti DA, Rondorf DW, Kraut JM. Migratory behavior an forebay delay of radio-tagged juvenile fall chinook salmon in a lower Snake River impoundment. N Am J Fish Manag. 2000; 20(1):41-52.

Winter JD. Advances in underwater biotelemetry. In: Murphy BR, Willis DW, editors. Fisheries techniques. 2nd ed. Bethesda: American Fisheries Society; 1996. p.555-590.

Submitted June 01, 2018 Accepted April 25, 2019 by David Hoeinghaus 